\title{
Investigation of brick masonry with using of bad quality of bricks and reinforced concrete frame
}

\author{
Andreas Triwiyono ${ }^{1, *}$, I Gusti Lanang Bagus Eratodi ${ }^{2}$ \\ ${ }^{1}$ Civil and Environmental Engineering Department, Universitas Gadjah Mada, Indonesia \\ ${ }^{2}$ Civil Engineering Department, Universitas Pendidikan Nasional, Indonesia
}

\begin{abstract}
In some region typical resident houses are made of brick masonry. Ministry of Public Work Indonesia and JICA [2] have published a guideline as key requirements for safer houses. A study was carried out to obtain the effect of disparities material quality on the performance of the brick masonry. Six wall specimens were experimentally tested in-plane direction until failure by observing deformation, cracks, and uprooting of the wall. Study based on the finite element was also used by implementing the threedimensional stress state of concrete and masonry and elastic-plastic for reinforcement. From the study it can be concluded that: the wall following guideline has enough strength but could not reach the load capacity because the wall was uprooted. Bad quality of concrete did not affect the stiffness and strength of the walls. The strength of the walls with a poor quality of mortar and poor quality of bricks comparison to the wall with standard quality of bricks had the strength of about $78 \%$. Wall without plastering with a poor quality of the bricks, mortar, and concrete reduced the strength and stiffness to about $41 \%$ compared to the wall with standard quality. The proposed FE model can predict the strength of the wall well but not for its stiffness. The model especially the masonry material model still needs to be developed in order to obtain the close result with the laboratory test.
\end{abstract}

\section{Introduction}

In some region typical resident houses are made of brick masonry with reinforced concrete (RC) tie columns and tie beams ( $\mathrm{RC}$ frame). This kind of structures generally built without structural analysis and design processes, this classified as non-engineering structures. Because of earthquakes, a number of houses were damaged. The most of the damaged houses were made of clay brick (bata merah) masonry. The damage depends on many parameters, i.e. quality of materials and construction method. Considering that improving performance of the houses has become important and priority. A pocketbook as guidance for seismic-resistant permanent structures especially for house made of brick masonry confined using reinforced concrete frame has been published by Department of Public Work and JICA [2]. The guidance is completed with illustrations, detailing of members and connections including materials requirements. Committee of International Experts [3] published a design guide for non-engineering building. In these guidances, there are some requirements, i.e. minimum size and quality of brick, mortar and concrete mixture, size of RC frame elements. Experiences showed that building failure often occurs due to the unmet material qualities and varied working methods. Some typical disparities are poor quality bricks, mortar, and concrete. Based on the variation in the implementation, several experimental studies of brick masonry walls confined by reinforced concrete frame had been conducted. The studies were reported by JICA-Institute for Human Settlements Research Team [7], [13], JICA-Research Team [14]. Several numerical studies had already done by some researcher [8-12]. Some numerical models for illustration of material properties (concrete, brick masonry, reinforcement) were proposed.

This paper reported the study of experimental testing and numerical analysis of brick masonry walls with a variation of the quality of bricks, mortar, and concrete. The study discussed some of the entire studies undertaken by the JICA-research team [14] by focusing on some parameters such as bad qualities of clay brick, mortar, and concrete coupled with numerical-based studies. These bad qualities cause unfilled requirements and were considered as the main reasons of failures and damages of the house structures occurrence of the seismic load. The studies also covered brick masonry wall with RC frame under horizontal load parallel to the wall plane.

\section{Methodology}

The methodology used in the study was an experimental test and numerical finite element analysis. The experimental test included tests on the material aspects of bricks, mortar, concrete and structural aspects of cyclic monotonic tests on specimens of the full-scale

\footnotetext{
* Corresponding author: andreas.triwiyono@ugm.ac.id
} 
confined brick masonry wall. The experiment has been carried out in Research Institute for Human Settlements in Bandung, Indonesia. The numerical analysis based on finite element method was done to know the internal forces of the specimen especially knowing the stresses on the walls, reinforced concrete frame, and anchorages between wall and foundation, which were not obtained in the experimental test. The analysis was done as static monotonic tests on full-scale brick masonry wall confined by reinforced concrete frame. Material properties obtained from the results of the experimental test. Some material characteristics as an input value of the FE analysis were assumed based on literature study [1].

reinforcement of the $\mathrm{RC}$ frame, anchorages between the brick wall and RC frame, anchorages between wall and foundation are shown in the same figure.

Some practice residence house was constructed by not following the requirements of the pocketbook [2], especially not good quality of brick, mortar and frame concrete. The typical pattern for the six wall specimens is presented in Table 1 .

Table 1. Wall pattern

\begin{tabular}{|c|c|c|c|c|}
\hline Pattern & Brick & Concrete & Mortar & Plastering \\
\hline 1 & Good & $\begin{array}{c}\text { Good } \\
(1: 2: 3: 0.8)\end{array}$ & Good & Plastering \\
\hline 2 & Good & $\begin{array}{c}\text { Poor } \\
(1: 2: 3: 1.2)\end{array}$ & Good & Plastering \\
\hline 3 & Good & Good & Poor & Plastering \\
\hline 4 & Poor & $\begin{array}{c}\text { Good } \\
(1: 2: 3: 0,8)\end{array}$ & Good & Plastering \\
\hline $5 \& 6$ & Poor & Poor & Poor & $\begin{array}{c}\text { Without } \\
\text { plastering }\end{array}$ \\
\hline
\end{tabular}

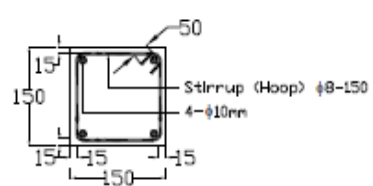

Column $15 \times 15 \mathrm{~cm}$

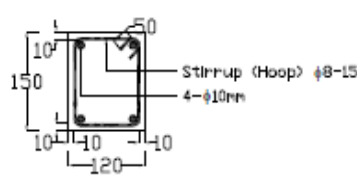

Ring Beam $12 \times 15 \mathrm{~cm}$

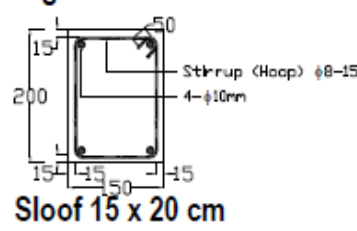

DET-A
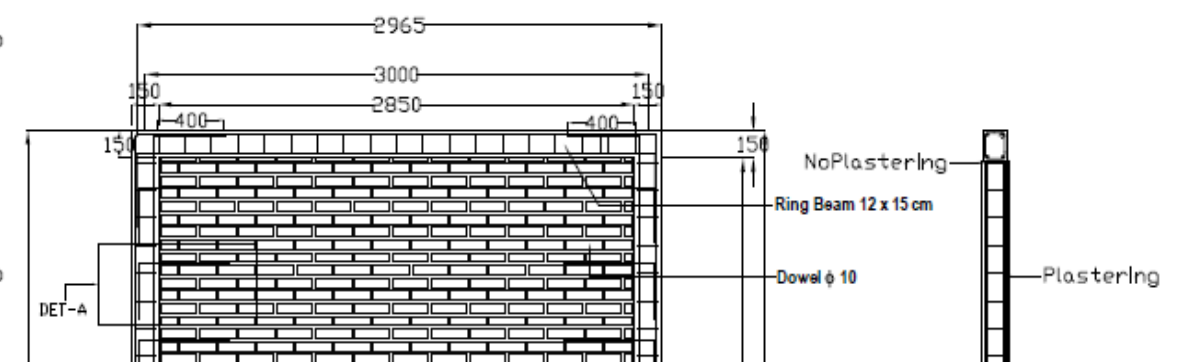

$15 \times 20 \mathrm{~cm}$
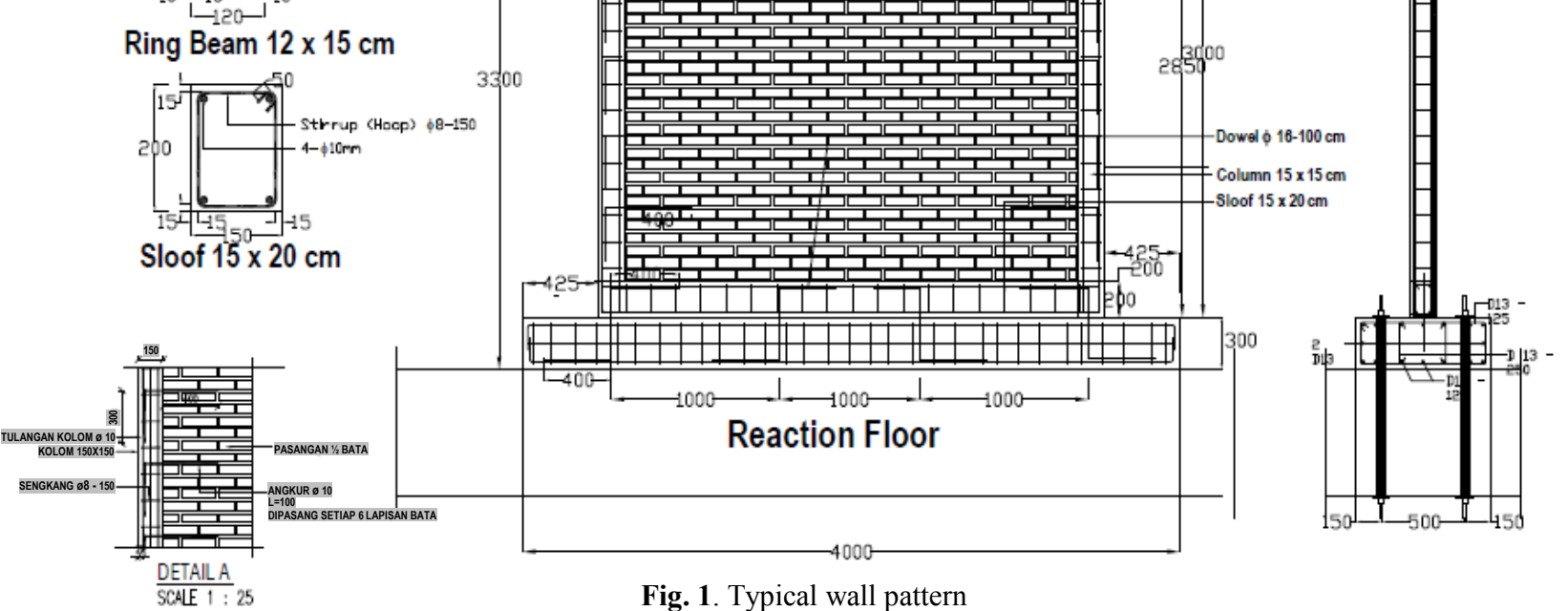

Fig. 1. Typical wall pattern

\subsection{Experimental test}

The wall specimens were constructed by using local materials. The bricks were made of clay with dimensions about $22 \mathrm{~cm}$ long by $10 \mathrm{~cm}$ wide and $5,5 \mathrm{~cm}$ thick, the manual product from the area near Bandung in West Java Province. The brick masonry walls with dimensions of $3.0 \mathrm{~m} \times 3.0 \mathrm{~m}$ is confined by RC frame, were constructed based on the key requirements published by the Department of Public Works Indonesia-JICA [2]. Horizontal anchorages were provided for each wall for every six bricklayers. The dimension and detailing of the wall are presented in Figure 1. Dimension and
The strength of brick can be qualitatively ascertained based on IAEE [1]: the good quality brick should be strong enough to support in bending of the weight of a man, Figure 2.
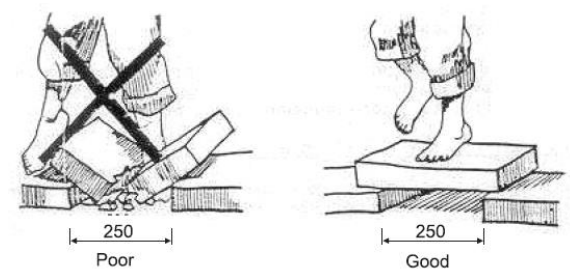

Fig. 2. Field testing of brick strength [1] 
The test set up is illustrated in Fig 3. The horizontal cyclic loads were applied along the ring beam in the direction of the strong axis of the wall. The loads were stopped after reaching the strength of the wall specimen and degraded about $25 \%$ of this maximum strength or after reaching about $3,5 \%$ drift ratio. The cyclic loading was applied based on FEMA 450 recommendation presented in Figure 3. Relative shear displacement of the wall was measured using Linear Variable Differential Transformer (LVDT).

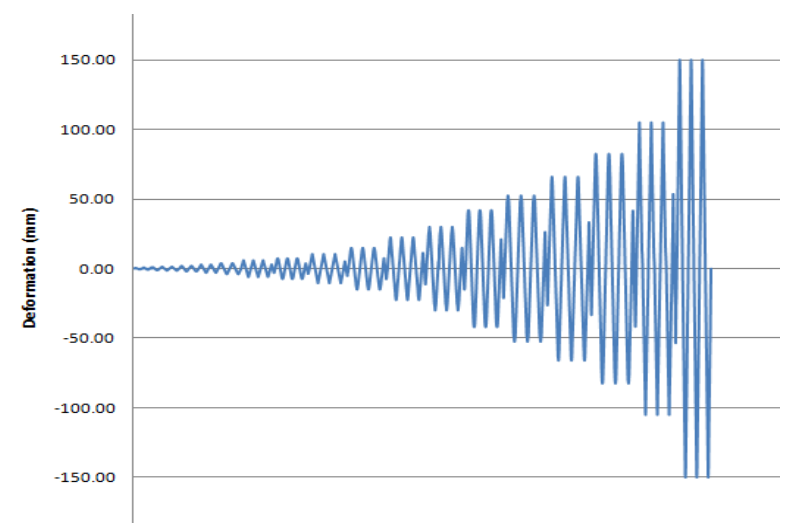

Fig. 3. Loading pattern based on FEMA 450

\subsection{Finite Element (FE) Analysis}

In the FE analysis, the reinforced concrete (RC) singlestory frame and the wall panel with dimensions of $3.0 \mathrm{~m}$ $\times 3.0 \mathrm{~m}$ and $15 \mathrm{~cm}$ thick were represented by plane stress elements. The reinforced concrete frame was also modeled as plane stress element. The interface between RC frame and brick masonry wall was modeled perfectly bond. In general, the RC frame confined masonry wall was modeled as continuum elements, where brick, mortar, and brick-mortar interface are smeared out in the continuum. The element stiffness is based on its actual dimensions and material properties. Eight-node plane stress element was used to discrete the masonry, columns and beams. Two-node truss element was used to implemented reinforcement. The bonding between concrete and reinforcement is considered as a perfect bond. The used elements were illustrated in Figure 4 and 5 .
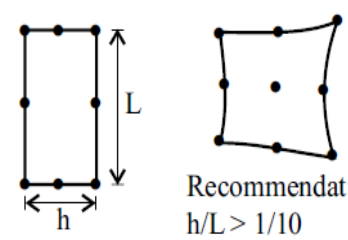

Recommendation: $\mathrm{h} / \mathrm{L}>1 / 10$

(a) 8-\& 9-node elements

Fig. 4. Plane stress element for wall and RC frame

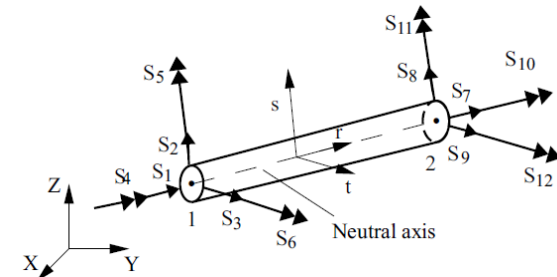

(a) Truss element for reinforcement

Fig. 5. Element use in numerical analysis of walls

The finite element software ADINA [4], which based on the finite element method, was adopted for numerical analysis. Orthotropic models are adopted to characterize the material, especially after cracking. The stress-strain relationship for concrete material in tension and compression is shown in Fig 6, where $\sigma_{t}$ denotes the tensile strength of the concrete and $\sigma_{t p}$ denotes the strength after cracking. In the compression state of stress, $\sigma_{c}$ denotes the compressive strength and $\sigma_{u}$ denotes the ultimate strength. The same material model was used for the brick masonry with modification of some material characteristics, in accordance with the test results of each material. Compressive strength of concrete, mortar and brick was obtained from laboratory test. The compressive strength of the brick masonry was approximated from the formula reported in [14]. The tensile strength of the both materials (concrete and masonry) was assumed to be about $10 \%$ of the each compressive strength.

Concrete failure criterion is adopted from Bathe and Ramaswamy [5]. The model has been calibrated with the yield surface from an experimental test [6], see Figure 7.

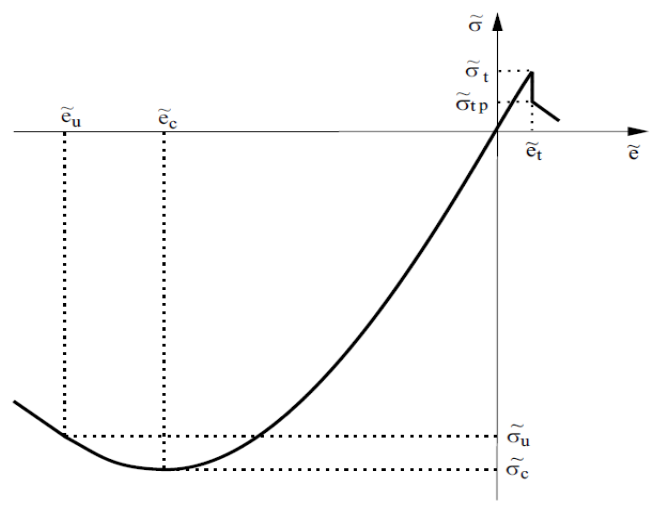

Fig. 6. Uniaxial stress-strain curve for concrete

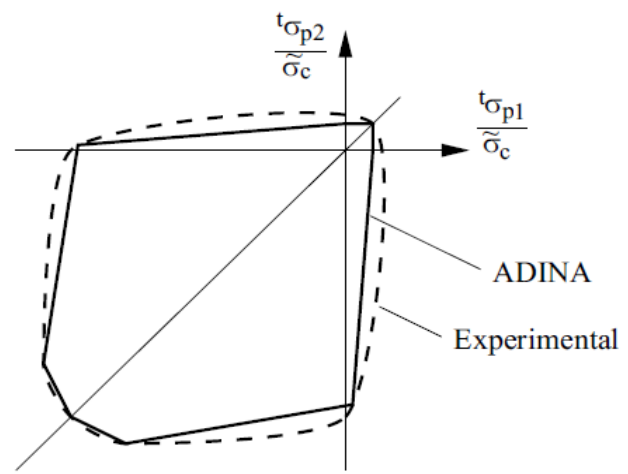

Fig. 7. Biaxial state of stress failure criterion of concrete [6] 
The wall was loaded to a lateral distributed force applied on the center long line of the top frame element. The wall model of the brick masonry before and after loading is illustrated in Figure 8 . The boundary conditions of based line of the wall is defined as restrained.

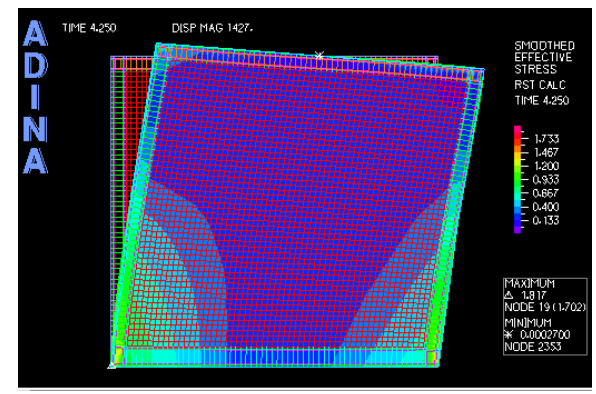

Fig. 8. Wall model by using ADINA software

The separation between both components is defined by cracks in the material model. The load-displacement curve as the output of the analysis of a wall model will be compared with the same curve of the same wall from the experimental results to determine whether the model is good enough to be used to determine the effect of material quality on wall behavior. The finite element model is also used to determine the force in the anchorage steel between the bottom beam of the wall and the foundation due to the horizontal load on the upper side of the wall.

\section{Result and Discussion}

\subsection{Material properties}

The material properties for clay brick, mortar and concrete, obtained from laboratory material test, were given in Table 2. The compressive strength of the clay bricks as masonry units was categorized as good and poor bricks and mortar with two characteristics (1PC:4 PS and 1PC:7PS). The average compressive strength of concrete with a composition of 1:2:3:0.8 and 1:2:3:1.2 for cement, sand, aggregate and water-cement ratio, which represented as good and poor concrete, were 19.079 $\mathrm{MPa}, 15.48 \mathrm{MPa}$, respectively.

Table 2. Material properties of the RC frame confined brick masonry

\begin{tabular}{|c|c|c|c|c|c|}
\hline \multirow{2}{*}{ Property } & $f_{c}^{\prime}$ & $f_{c}^{\prime}$ & \multicolumn{3}{|c|}{ Brick masonry } \\
\cline { 4 - 6 } & Brick \\
$(\mathrm{MPA})$ & $\begin{array}{c}\text { Mortar } \\
(\mathrm{MPa})\end{array}$ & $\begin{array}{c}\text { Compr. } \\
\text { strength } \\
(\mathrm{MPa})\end{array}$ & $\begin{array}{c}\text { Tensile } \\
\text { strength } \\
(\mathrm{MPa})\end{array}$ & $\begin{array}{c}\text { Mod of } \\
\text { Elaticit } \\
\mathrm{y} \\
(\mathrm{MPa})\end{array}$ \\
\hline Good & $\begin{array}{c}5.80 \\
\mathrm{MPa}\end{array}$ & 8.943 & 3.254 & 0.21 & 2400 \\
\hline Poor & $\begin{array}{c}4.23 \\
\mathrm{MPa}\end{array}$ & 7.515 & 2.575 & 0.15 & 2100 \\
\hline
\end{tabular}

\subsection{Behaviour of the Masonry Walls}

From reading the load and deflection of the upper end of the wall at each cycle can be made a curve of the hysteresis loop. Figure 9 shows the hysteretic loop of the wall pattern 1, the same curve of other wall patterns were reported in [14]. Figure 10-14 shows the envelope curve for all wall patterns, that were obtained from each hysteretic loop. In the same figure are shown also the load-deflection curve of the walls from the results of FE analysis. From the hysteretic loops or envelope curves, several key parameters of the wall can be evaluated, namely, maximum lateral load carrying capacity, stiffness, yield capacity and ductility.

Wall of pattern 2 with different quality of concrete for columns and beams of the confining frame, each wall behaved similarly. The poor quality of concrete did not affect significantly the stiffness of the wall in the elastic range. The strength of the wall pattern 2 was equal to wall pattern 1 and the degradation curve after reaching maximum load were similar.

The strength of the wall pattern 3 reduced to about $8 \%$ of the maximum load compared to the standard quality wall (wall pattern 1). The poor quality of brick affects hardly the strength of the wall, the strength was about $78 \%$ compared to the following guidance wall. Walls with poor quality materials (brick, mortar, and concrete) and without plaster only have the strength of about $41 \%$ of the standard wall.

From the envelope curve, crack patterns and failure mode of the test results can be concluded as well, if the quality of the brick is good then the strength of the wall is high enough and the degradation of the strength, after reaching the load capacity, is slowly without collapse. For poor brick quality, the wall has low stiffness and strength even though the masonry wall is confined by $\mathrm{RC}$ frame.

From the finite element analysis, it was found that the strength of the most walls obtained from finite element model was close to laboratory test, see Fig 11 and 13, but the stiffness was not. This stiffness difference is probably due to material model, especially the model of masonry approached by concrete. The masonry material model still needs to be developed in order to obtain the value that is close to the same result with the laboratory test.

The experimental test of the wall also reveal that the proportional limit of the curve was determined by the damage of the brick walls, not by the crack or broken off the concrete and the yielding of the reinforcement bars. The proportional limit is greatly affected by the first crack of the masonry wall. The initial stiffness and degradation of the strength after reaching the load capacity are influence successively in the absence of the plaster, brick quality and concrete quality. 


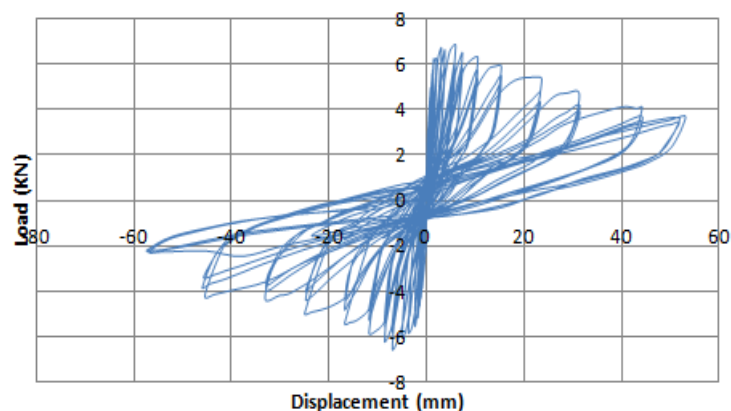

Fig. 9. Hysteretic loop of the wall pattern 1

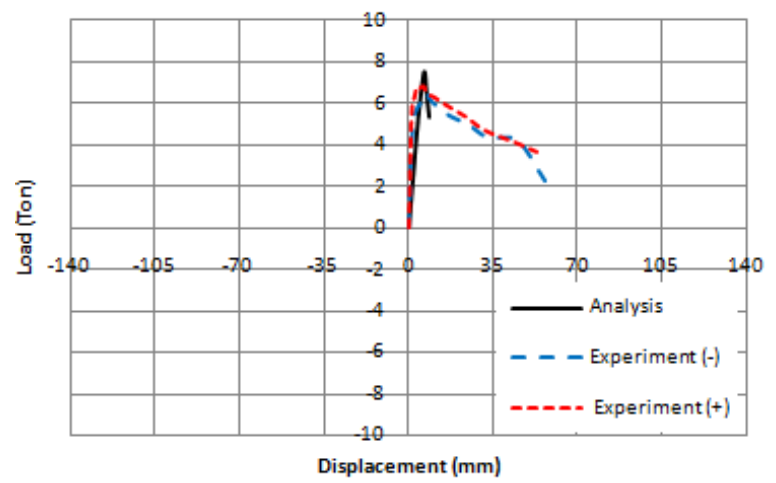

Fig. 10. Envelope curve of the wall pattern 1

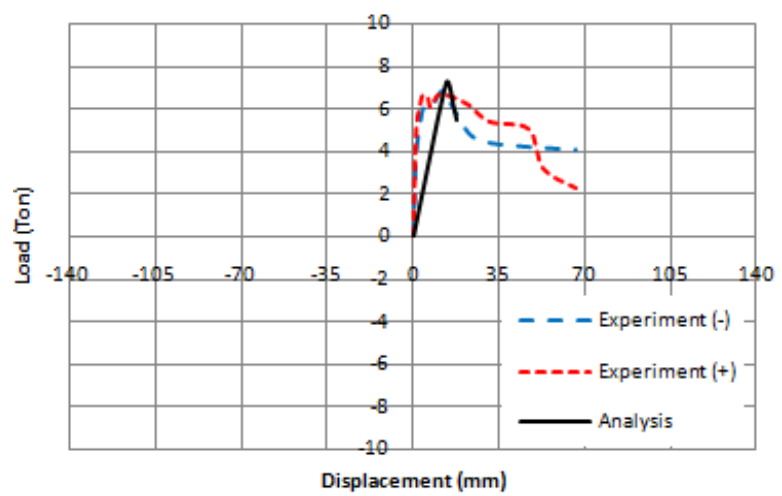

Fig. 11. Envelope curve of the wall pattern 2

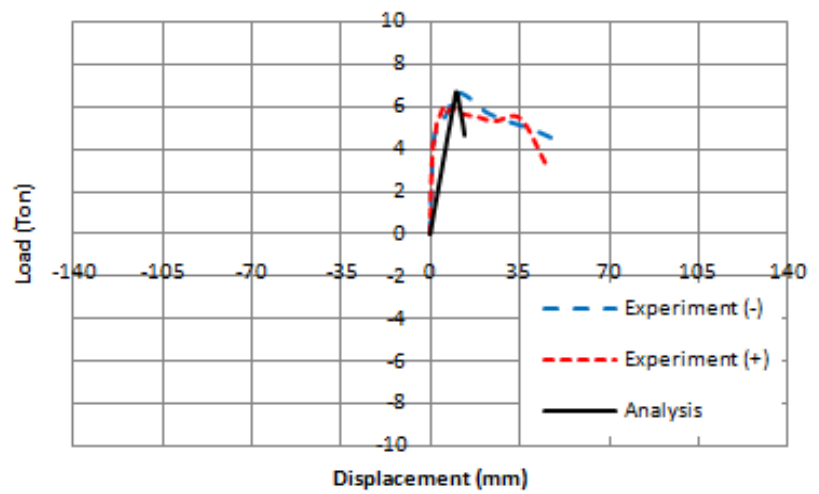

Fig. 12. Envelope curve of the wall pattern 3

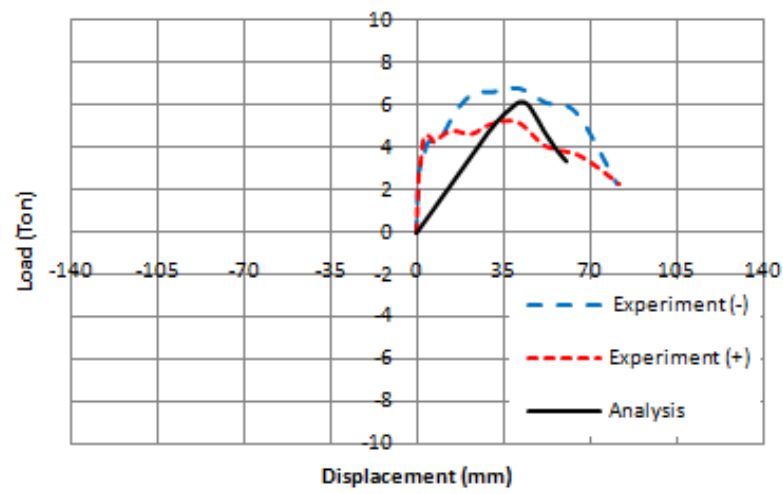

Fig. 13. Envelope curve of the wall pattern 9

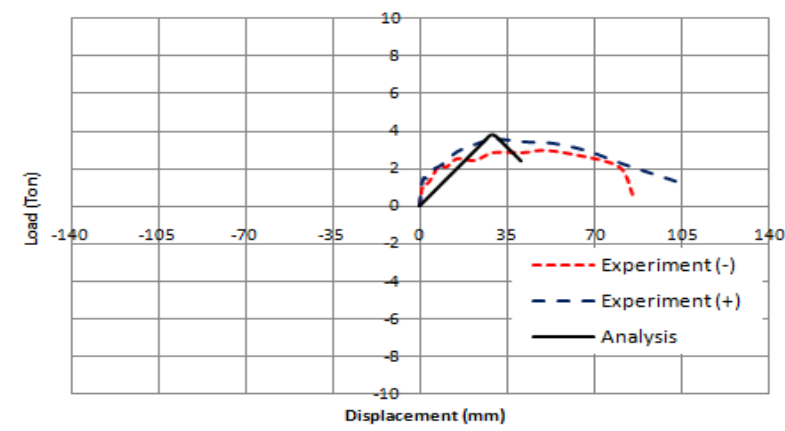

Fig. 14. Envelope curve of the wall pattern 13

Evaluation on the steel rebars using strain gauges reveals that the steel reinforcement of the frame members not reached yield until the test stopped. The anchorage bars (shear connector) in the bottom corner of the wall started to yield when the drift of the structure reached about $2.4 \%$. The observation also reveals that uplift occurred before reaching the maximum load capacity (wall pattern 1 dan 2), see Fig. 15 and 16. It was unthinkable the separation between the sloof beam and the foundation, even though a steel anchorages were installed. The stress of the steel bars and uplift are also found by the FE model.

The connection system between the wall and foundation in this experimental test used shear connectors that connected bottom beam with the foundation. It seems that the connection between the wall and foundation should use reinforced bars of the columns directly anchored to the foundation to avoid uplift. This detailing is recommended to be used for further studies.

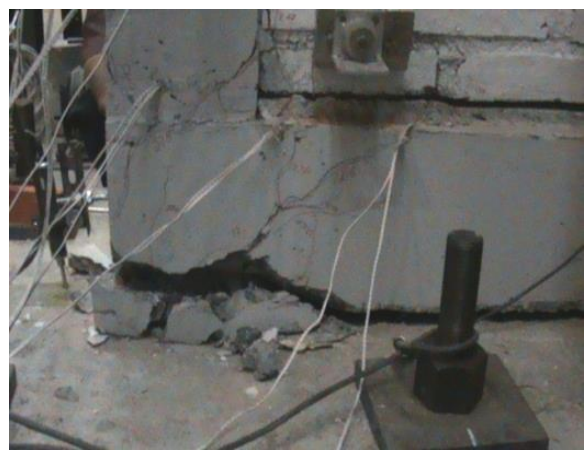

Fig. 15. Separation occurred between tie beam and foundation 


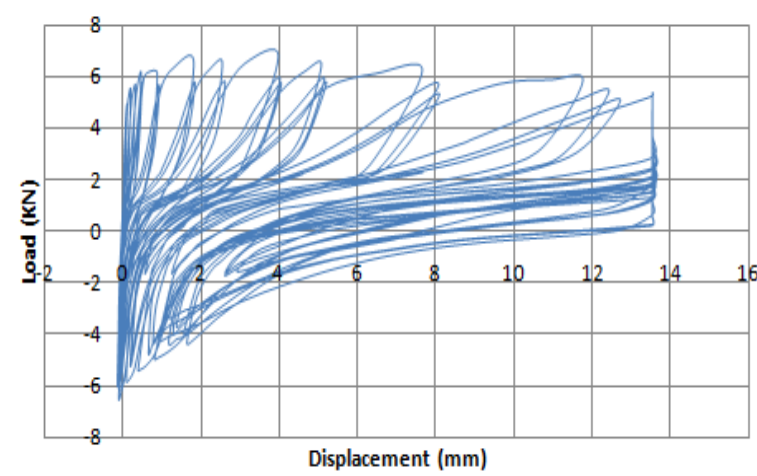

Fig. 16. The load-displacement curve of the base of the tie bean relatively from the foundation

\section{Conclusion}

The results of the study of brick masonry with using the bad quality of bricks, mortar, and concrete can be concluded as follows:

a. The wall following guideline has enough strength but could not reach the maximum load capacity because the anchorage at the bottom of the wall was uprooted.

b. Bad quality of frame concrete did not affect significantly the stiffness and strength of the walls.

c. The strength of walls with a poor quality of bricks comparison to the wall with standard quality bricks had the strength of about $78 \%$.

d. Wall without plastering with a poor quality of the bricks and RC frame, the strength and stiffness reduced to about $42 \%$ compared to the wall with standard quality.

e. FE model can predict the strength of the wall well but not for its stiffness. The model especially the masonry material model still needs to be developed in order to obtain to the close result with the laboratory test.

The experimental study was conducted with financial from Japan International Cooperation Agency (JICA) in collaboration with Universitas Gadjah Mada and Universitas Islam Indonesia, had been done in Structure Laboratory Research Institute for Human Settlements (RIHS), Agency for Research and Development, Ministry of Public Works. Thank you to the head and all staff of the laboratory, who have assisted the testing and recording of the data and the hospitality during the test.

\section{References}

1. International Association for Earthquake Engineering (IAEE), Guidelines For Earthquake Resistant Non-Engineered Construction, Gakujutsu Bunken Fukyu-Kai, Tokyo (1986).

2. Department of Public Works Indonesia and Japan International Cooperation Agency (JICA), The Hand Book of Principal Requirements for Safer Houses, Jakarta (2009).
3. R. Meli, S. Brzev, M. Astroza, T. Boen, F. Crisafulli, J. Dai, M. Farsi, T. Hart, A. Mebarki, A.S. Moghadam, D. Quiun, M. Tomazevic, and L. Yamin, Seismic Design Guide for Low-Rise Confined Masonry Buildings, A Project of the World Housing Encyclopedia, EERI \& IAEE, Committee Of International Experts (2011).

4. K.J. Bathe, Automatic Dynamic Incremental Nonlinear Analysis ADINA Solid and Structures, ADINA R \& D, Inc. Watertown, USA (2010).

5. K.J. Bathe, and S. Ramaswamy, On Three Dimensional Nonlinear Analysis of Concrete Structures, Journal of Nuclear Engineering and Design, S2, 385-409 (1977).

6. H. Kupfer, Das Verhalten des Betons unter mehrachsiger Kurzzeitbelastung unter besonderer Beruechsichtigung der zweiachsigen Beanspruchung, Heft 299 des deuthen Ausschusses fuer Stahlbeton, Wilhelm Ernst \& Sohn, Berlin (1973).

7. Research Institute for Human Settlements, Lateral Loading Test of Confined Masonry Wall and Pull Down Test of Full Scale Confined masonry House Model (2012).

8. G.M. Fonseca, R.M. Silva, and P.B. Lourenço, The Behavior Of Two Masonry Infilled Frames: A Numerical Study, http://www.civil.uminho.pt/ masonry/Publications/Update Web page/1998 Fonseca_Silva.pdf (1998).

9. P.G. Asteris, Lateral Stiffness of Brick Masonry Infilled Plane Frames, Journal of Structural Engineering (C) ASCE / August (2003).

10. B. Budiono and Hernawi, Model Elemen Hingga Non Linier Untuk Karakterisasi Panel Dinding Bata Pengisi Terhadap Gaya Lateral Siklik, PROC. ITB Sains \& Tec. 35 A, 129-145 (2003)

11. G. Mondal and S.K. Jain, Lateral Stiffness of Masonry Infilled Reinforced Concrete (RC) Frames with Central Opening, Earthquake Spectra, 24, 701723, August, Earthquake Engineering Research Institute (2008)

12. B. Badarloo, A.A. Tasnimi, and M.S. Mohammadi, Failure Criteria of Unreinforced Grouted Brick Masonry Based on a Biaxial Compression Test, Transaction A: Civil Engineering, 16, 502 - 511 (2009).

13. Research Team Research Institute for Human Settlements, Report of Full Scale Testing of Indonesian Confined Masonry House, Ministry of Public Works, Agency for Research and Development Research Institute for Human Settlements (2010).

14. JICA Team Research, Report Of The Survey Of Construction Method, Peoples Awareness And So On Experiment And Numerical Study Of Masonry Confined Wall (2012). 